\title{
Prevalence of parasitic Infections and its Effect on the Health Status of Primary School Children.
}

\author{
${ }^{1}$ NahedKaram Mahmoud El-sehry, ${ }^{2}$ Latifa Mahmoud Fouda, \\ ${ }^{3}$ LulahAbdEl-WahabAbdEl-Aty Hassan \\ ${ }^{I}$ Demonstrator, \\ ${ }^{2}$ Professor, \\ ${ }^{3}$ lecturerofCommunity Health Nursing Department, Faculty of Nursing, Tanta University. \\ Corresponding Author: LulahAbd El-WahabAbd El-Aty Hassan
}

\begin{abstract}
Background: Intestinal parasitic infections are one of the neglected tropical diseases and it is most common among school children. It negatively affects children growth, cognitive development and learning abilities. It may lead to nutritional deficiencies and anemia.

Aim of the study: To assess the prevalence of parasitic infections and its effect on the health status of primary school children.

Research design: Descriptive cross sectional research design.

Subjects and method: This study was conducted at rural governmental primary schools in El Mehalla El Kobra district.

Tools of data collection: Two tools were used.

Tool I: An interview sheet composed of three parts. (1) Bio-socio-demographic characteristic of the pupils (2) Practice of personal hygiene (3) Knowledge of pupils about parasitic infections.

Tool II: Nutritional assessment tool composed of five parts. (1) Anthropometric measurement such as measuring weight and height then calculation of body mass index (BMI), (2) Stool analysis, (3) Examination of blood hemoglobin level, (4) Physical signs of malnutritionand (5) Mini nutritional assessment scale.

Results: More than three quarters (79\%) of the studied school children were infected by intestinal parasite. More than half (56.0\%) of the studied school children were infected by one parasite, and nearly one quarter (23.0\%) were infected by two parasites.Moreover, $75.5 \%$ of the infected students by parasites had moderate anemia.

Conclusion and recommendation: The present study revealed that, all of the studied pupils had poor knowledge score about intestinal parasitic infections. Health education programs are strongly recommended to raise the awareness of school children about parasitic infection and to motivate them to use the preventive measures.
\end{abstract}

Keywords: Parasitic infection, school children

\section{Introduction}

Children are vulnerable group in the community, their health is vital to the future of society. School age is segment of life span that extends from age 6-12 years of age. School children are main target to many health problems such as malnutrition, non-infectious diseases and infectious diseases as intestinal parasitic diseases. The intestinal parasites are among the most common infections of school age children in developing countries ${ }^{(1-}$ 5). Not only in the developing countries, but all-over the world intestinal parasitic infections (IPIs) still considered one of the major causes of public health problems ${ }^{(6,7)}$.According to World Health Organization (WHO) in year 2014, more than 1.5 billion people or $24 \%$ of the world's population are infected with soiltransmitted helminthic infections worldwide. Over 270 million preschool-age children and over 600 million school-age children live in areas where these parasites are intensively transmitted, and are in need of treatment and preventive interventions ${ }^{(8)}$.In Egypt, several studies were conducted for determination of the prevalence of intestinal parasitic diseases among school children. Among these studies, a study was conducted in AL-Azhar and Assuit University in year 2010 and the result of this study showed that $38.5 \%$ was the overall percentage of parasitic infections ${ }^{(9)}$. Another study conducted in Minia governorate in year 2011 revealed $19.3 \%$ for Entamoeba coli, $3.8 \%$ for Ascarislumbricoides, $12.5 \%$ for Hymenolepiasis nana, $5.7 \%$ for Enterobiousvermicularis and $12.5 \%$ for Gairdialambia ${ }^{(10)}$. And other study conducted in Damiette governorate in 2012 showed $30.7 \%$ as the overall percentage ofparasitic infections ${ }^{(11)}$. 
Parasites are organisms larger than yeast or bacteria that can cause infection. They live in a host and get its food from or at the expense of its host. Human intestinal parasites populate the gastro-intestinal tract of humans. It has become a major health problem in many developing countries. ${ }^{6,12,13)}$.

School children carry the heaviest burden of the parasite- associated morbidity due to many factors. These factors may include children's dirty habits of playing or handling of infested soils, eating with soiled hands, unhygienic toilet practices, drinking and eating of contaminated water and food (e.g. Ascariasis, Trichuriasis, Giardia lamblia) and sharing toys, bedding, clothing and toilet seats (e.g. oxyuris) and because of their vulnerability to nutritional deficiencies ${ }^{(13,14)}$

Various factors affect the prevalence and intensity of intestinal parasitic infection. They include lack of adequate or proper sanitation facilities, behavioral factors, age, socio-economic factors and geographical factors ${ }^{(15)}$.Intestinal parasitic worms are generally contracted via many routes; direct via ingesting parasite eggs or larva (e.g. Ascariasis and oxyuris) or indirect ingestion via contaminated articles, fomites and clothes and direct penetration while walking barefooted on contaminated soil (e.g. Ancylostomaduodenale) ${ }^{(16)}$.

In developing countries, poor environmental and personal hygiene, overcrowding and climatic conditions that favor the development and survival of these parasites are some of the factors contributing to the high level of intestinal parasites transmission ${ }^{(17) .}$ Food handlers play an important role in their transmission. Ignorance is also a contributing factor to transmission especially among people living in rural areas where level of awareness is relatively low ${ }^{(18)}$. Infection with intestinal parasites has known to cause iron deficiency anemia, growth retardation in children and other physical and mental health problems. Furthermore, chronic intestinal parasitic infections have become the subject of speculation and investigation in relation to the spreading and severity of other infectious diseases of viral origin, tuberculosis and malaria ${ }^{(19-21)}$.

Although treatment with the current anti-helminthic can significantly reduce parasite burdens, chemotherapy alone is unlikely to prevent reoccurring infections with GI nematodes. Infections are best controlled by integrated strategies, involving the provision of clean water, better housing, improvements in sanitation and hygiene, health education and the general nutritional status, and the strategic use of combinations of chemotherapeutic anti-helminthic. Using such integrated control programs, strategic utilization of the current anti-helminthic drugs will prolong their efficacy and delay the onset of resistance ${ }^{(2,23)}$.Also, integrated control programs of intestinal parasites require coordination and collaboration of health staff at the central and district levels and between the Ministries of Health and Education and the other ministries concerned (the Ministries of Finance and Communications, Environment, and Community and Development). Through the school system approach and with the support of the national press and other media, community participation has been stimulated to control IPIs ${ }^{(24)}$.

School health nurse has important role in the prevention and control of parasitic diseases. She educates children and trains them in their care and about personal hygiene measures such as: keeping finger nails short, avoiding scratching of perianal area and nail biting, wash hands as good hand hygiene is the most effective preventive measures especially after using the bath room and before eating and avoid sucking thumb, especially for Oxyuris, Ascriasis andTrichuriasis. Encourage children to wear shoes and avoid going barefoot, especially forAncylostomaduodenale ${ }^{(25-27)}$.

\section{Aim Of The Study}

The aim of this study was to assess the prevalence ofparasitic infection and its effect on the health status of primary school children.

\section{Research question:}

1. What is the prevalence ofparasiticinfection among primary school children?

2. What is the effect of this infection on the health status of children?

\section{Subjects}

\section{Subjects And Method}

\section{Study design:}

Descriptive cross sectional study design was used in this study.

Setting: This study was conducted at governmental primary schools at El-MehallaEl-Kobrarural areas.

\section{Subjects:}

The total number of the study sample was 300 students (boys\& girls). The sample chosen randomly from the previous setting by proportion allocation method representing approximately $1.93 \%$ according to each district as the following table:-

\begin{tabular}{|l|l|l|l|l|l|}
\hline \multirow{2}{*}{$\begin{array}{l}\text { Distribution of students according } \\
\text { to district }\end{array}$} & East & West & \multirow{2}{*}{ Total } \\
\cline { 2 - 5 } & Boys & Girls & Boys & Girls & \\
\hline Total student's number & $\mathbf{2 9 5 1}$ & $\mathbf{2 7 7 0}$ & $\mathbf{4 8 5 5}$ & $\mathbf{4 9 6 9}$ & $\mathbf{1 5 5 4 5}$ \\
\hline Selected sample number & $\mathbf{5 7}$ & $\mathbf{5 3}$ & $\mathbf{9 4}$ & $\mathbf{9 6}$ & $\mathbf{3 0 0}$ \\
\hline
\end{tabular}


Tools of the study: -

Two tools were used by the researchers to obtain the necessary data:-

Tool I: An interview sheet: it was developed by the researchers and included the following parts: -

Part I: Bio socio demographic characteristic of the students: it included data about age, sex, grade of education of students, parents' education and occupation, residence, number of brother and sisters and history of parasitic infection.

Part II: Practice of personal hygiene: this part included data about general hygiene/ grooming, cleanliness of hands and nails, hand washing after defecation or before eating, sharing underwear with other sisters or brothers, washing vegetables before eating, eating from street vendors and working at farm.

Part III: Knowledge of students about parasitic infections: This part aimed to assess students ' knowledge about parasitic infection. It covered the following areas; definition of helminthic infection, mode of transmission, signs $\&$ symptoms, types, complications and prevention of parasitic diseases.

The respondent was given 2 points for each correct and complete answer, 1 point for correct incomplete answer and zero for wrong answers. The total score of knowledge was calculated by summation of the score of all questions related to knowledge about parasitic infection and it equaled 24 points. The total amount of score summation of each pupil was divided by maximum score of knowledge and multiplied by 100 to get the total score percentage. The score of knowledge was classified into:-

- Poor knowledge (less than $60 \%$ of the total score).

- Fair knowledge (60-75\% of the total score).

- Good knowledge more than (75\% of the total score).

Tool II: Nutritional assessment tool: It included five parts:

Part I: Anthropometric measurements: It included height and weight and then calculation of body mass index (BMI) was done.BMI was plotted on center for disease control (CDC) growth charts to determine BMI for sex and age. Students' weight was categorized according to BMI percentile as shown in the following table ${ }^{(28)}$.

\begin{tabular}{|l|l|}
\hline \multicolumn{1}{|c|}{ Category } & \multicolumn{1}{c|}{ BMI (children 2-20 years) } \\
\hline \hline Underweight & BMI for age and sex $<5^{\text {th }}$ percentile \\
\hline Normal weight & BMI for age and sex $\geq 5^{\text {th }}$ percentile to less than the $85^{\text {th }}$ percentile \\
\hline Overweight & BMI for age and sex $\geq 85^{\text {th }}$ percentile to less than the $95^{\text {th }}$ percentile \\
\hline Obese & BMI for age and $\operatorname{sex} \geq 95^{\text {th }}$ percentile \\
\hline
\end{tabular}

Part II: Stool analysis of children: A stool sample of each participant student was obtained and tested to find out any parasitic infection.

Part III: Examination of blood hemoglobin level: A blood sample of each participant student was obtained and tested for hemoglobin level to determine the presence of anemia and its degree.The degree of anemia was assessed based on WHO recommended hemoglobin $(\mathrm{Hb})$ cut-offs points for children aged 5-11 years old as follows ${ }^{(29)}$.

- $11.5 \mathrm{~g} / \mathrm{dl}$ or higher $======$ No anemia

- $11.0-11.4 \mathrm{~g} / \mathrm{dl} \quad=======$ Mild anemia

- $8-10.9 \mathrm{~g} / \mathrm{dl} \quad======$ Moderate anemia

- Lower than $8.0 \mathrm{~g} / \mathrm{dl}=======$ Sever anemia

Part IV:Physical signs of malnutrition. Assessment of each student for physical signs of malnutrition was done.

It included assessment of hair, face, eyes, and lips.

Part V:Use Mini nutritional assessment (MNA) scale.

The MNA was developed by Nestlé nutrition institute and leading international geriatricians in the year 1994 and updated in 2009. Itis a screening tool to help identify elderly patients who are malnourished or at risk of malnutrition. It was adapted to assess nutritional status of children. Each student assessed for nutritional status by using MNA scale which included data about number of full meal child consumed per day, selected consumption markers for protein intake,daily intake of fruits and vegetables and degree of food intake also assessed $^{(30)}$.

\section{Method}

\section{1- Administrative approval:}

Before conducting the study, a written permission letter was obtained from faculty of nursing, Tanta University directed to the ministry of education then other letters directed to schools directors to obtain their approval and cooperation for carrying out the study. 


\section{2- Developing the tools:}

Study tools were developed by the researchers based on literature review. Then tools of the study were introduced to jury committee (two professor of community health nursing, one professor of pediatrics department in the faculty of nursing, Tanta University and two professors of public health in the faculty of medicine, Tanta University) before conducting the study for testing the face and content validity.

\section{3- An informed consent was obtained from the chosen schools students and their parents to participate} in the study.

4- The pilot study:

A pilot study was carried out on 30 students (10\% of the study sample) to test the clarity and applicabilityof the tools, estimate the time needed to fulfill it, as well as to identify any obstacles or problems in data collection. These students were not included in the study sample.

5- The actual study:

- Meeting with the students in the class rooms was done to explain purpose and the benefits of the study at the beginning of interview in the school.

- The data were collected over a period of one month starting from the first of to the end of December 2014.

- The researcher was available in the schools three days/week, but the first week at the beginning of data collection was available all days of the week from $8 \mathrm{Am}$ to $1 \mathrm{Pm}$. Sometimes the researcher was available in the afternoon schools from $12 \mathrm{Pm}$ to $4 \mathrm{Pm}$.

- The average time needed for each student to fill the sheet ranged from 10-15 minutes and the numbered of filled sheet per day was about 25-28 sheet.

- Confidentiality and privacy was put into consideration regarding the data collected.

\section{6- Analysis of the data:}

The collected data were organized, tabulated and statistically analyzed using Statistical Package for Social Studies (SPSS) version 19 created by IBM, Illinois, Chicago, USA. For numerical values the range mean and standard deviations were calculated. The differences between mean values of knowledge in relation to parasitic infections were used using Mann-Whitney test as the data were showing high variance. For categorical variable the number and percentage were calculated and differences between subcategories were tested by chi square $\left(\mathrm{X}^{2}\right)$. When chi square was not appropriate Monte Carlo exact testes was used. The level of significant was adopted at $\mathrm{p}<0.05$.

\section{Results}

Table (1) showed the distribution of the studied subjects according to their socio demographic characteristics. It showed that, the age of the studied students ranged from 6-11years with a mean $8.82 \pm 1.77$ years. More than half $(58.3 \%)$ of the study group their age ranged from $9-11$ years while $(41.7 \%)$ of them their age ranged from 68 years. The table also illustrated that nearly males and females were equal numbers $(50.3 \%, 49.7 \%)$ respectively. As regard to school grade, more than half of the study groups $(58.3 \%)$ were in the fourth grade compared to $(41.7 \%)$ in the first grade. Also the table showed that those who were first child in the family constituted the highest percentage of the studied students (83.3\%). Furthermore, more than half of the studied students (54.3\%) their crowding index was $>1.5$ while the rest of them $(45.7 \%)$ their crowding index was $<1.5$.

Table (1): Distribution of studied students according to their socio-demographic characteristics

\begin{tabular}{|c|c|c|}
\hline \multirow{2}{*}{ Variables } & \multicolumn{2}{|c|}{ The studied sample $(\mathrm{n}=300)$} \\
\hline & No & $\%$ \\
\hline \multicolumn{3}{|l|}{ Age in years: } \\
\hline - $\quad 6-8$ & 125 & 41.7 \\
\hline - $\quad 9-11$ & 175 & 58.3 \\
\hline Mean \pm SD & $8.82 \pm 1.77$ & \\
\hline \multicolumn{3}{|l|}{ Gender: } \\
\hline - $\quad$ Males & 151 & 50.3 \\
\hline - Females & 149 & 49.7 \\
\hline \multicolumn{3}{|l|}{ School grade: } \\
\hline - First & 125 & 41.7 \\
\hline - $\quad$ Fourth & 175 & 58.3 \\
\hline \multicolumn{3}{|l|}{ Birth order: } \\
\hline - 1 & 250 & 83.3 \\
\hline - 2 & 21 & 7.0 \\
\hline - 3 & 22 & 7.3 \\
\hline - $4-5$ & 7 & 2.4 \\
\hline \multicolumn{3}{|l|}{ Crowding index: } \\
\hline - $\quad<1.5$ & 137 & 45.7 \\
\hline - $\quad>1.5$ & 163 & 54.3 \\
\hline
\end{tabular}


Table (2) showed the distribution of the studied students according to their history of parasitic infection. It was observed that slightly less than two thirds (63.7\%) had previous personal history of parasitic infection while slightly more than half of the study groups $(57.7 \%)$ had no family history of parasitic infection. The majority of the studied subjects $(89.0 \%)$ who had previous history of parasitic infection detected it through routine screening tests. In relation to previous treatment for parasitic infection, slightly less than half of the studied students $(49.0 \%)$ received treatment directly after diagnosis.

Table (2): Distribution of studied subjects according to their history of parasitic infections

\begin{tabular}{|c|c|c|}
\hline \multirow{2}{*}{ Variables } & \multicolumn{2}{|c|}{ The studied sample $(n=300)$} \\
\hline & No & $\%$ \\
\hline $\begin{array}{c}\text { Family history of parasitic infection } \\
\text { - Yes } \\
\text { - No }\end{array}$ & $\begin{array}{c}127 \\
173 \\
\end{array}$ & $\begin{array}{l}42.3 \\
57.7 \\
\end{array}$ \\
\hline $\begin{array}{c}\text { Previous personal history of parasitic infection } \\
\text { - Yes } \\
\text { - } \quad \text { No } \\
\end{array}$ & $\begin{array}{l}191 \\
109\end{array}$ & $\begin{array}{l}63.7 \\
36.3 \\
\end{array}$ \\
\hline $\begin{array}{c}\text { Detection of parasitic infection by: } \\
\text { - } \quad \text { Presence of parasitic infection manifestations } \\
\text { - } \quad \text { Presence of parasitic infection complications } \\
\text { - } \quad \text { Routine screening tests }\end{array}$ & $\begin{array}{c}\text { Previous } \\
19 \\
2 \\
170\end{array}$ & $\begin{array}{c}=191) \\
9.9 \\
1.0 \\
89.0\end{array}$ \\
\hline 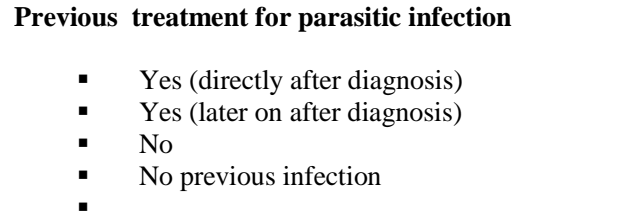 & $\begin{array}{c}147 \\
28 \\
16 \\
109\end{array}$ & $\begin{array}{c}49.0 \\
9.3 \\
5.3 \\
36.3\end{array}$ \\
\hline
\end{tabular}

Figure (1): represented the distribution of the studied subjects byprevalence of intestinal parasitic infections. The figure revealed that about three quarter of the studied school children (79\%) was infected by intestinal parasites. On the other hand, less than one fifth(21.0\%) of studentswere not infected by any intestinal parasite.

Figure (1): Distribution of studied subjects by prevalence of intestinal parasitic infections

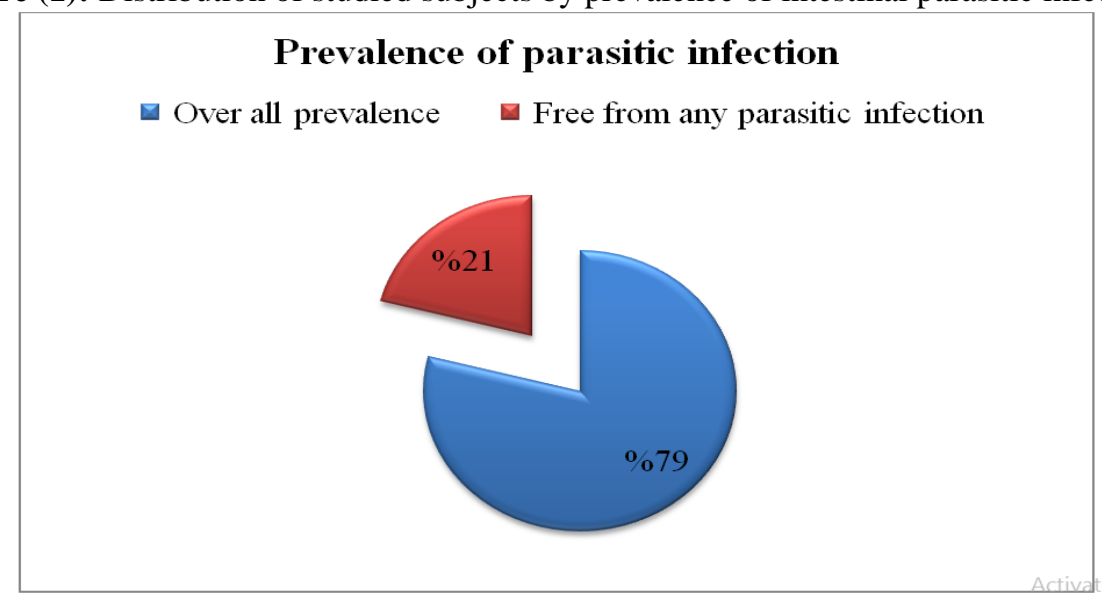

Figure (2) represented the distribution of the studied subjects by types of intestinal parasitic infections. It was observed that about three quarter of the studied students $(72.3 \%)$ were infected by entemebahistolytica compared to $(19.3 \%)$ were infected by oxyuris and $(8.7 \%)$ were infected by ascaris. The figure also showed that, only $(1.3 \%$, and $1.0 \%)$ were infected by giardia lamblia and hymenolepis nana respectively.

Figure (2): Distribution of studied subjects by types of intestinal parasitic infections.

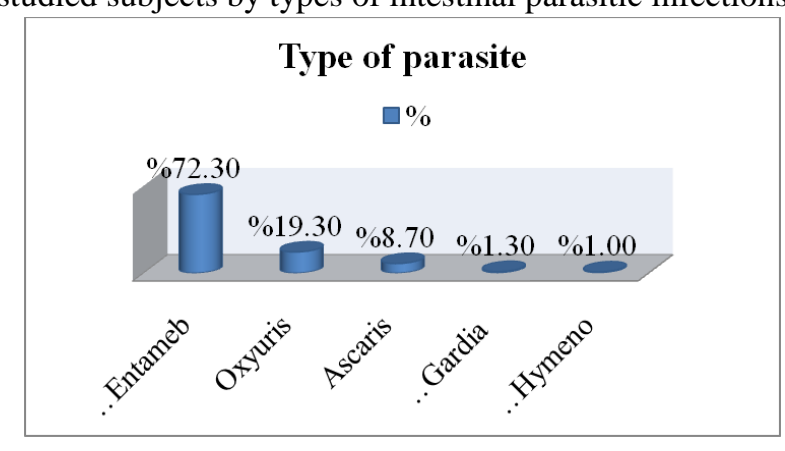


Table (3) showed the distribution of studied students according to their percentage of total knowledge score about parasitic infections. The table showed that all studied subjects had poor knowledge $(<60 \%)$ about intestinal parasitic infection with a mean $13.92 \% \pm 12.33 \%$.

Table (3): Distribution of studied students according to their percentage of total knowledge score about parasitic infections

\begin{tabular}{|c|c|c||}
\hline \multirow{2}{*}{ Total Knowledge score } & \multicolumn{2}{|c|}{ The studied sample (n=300) } \\
\cline { 2 - 3 } & No & $100 \%$ \\
- Poor knowledge $(<60 \%)$ & 300 & $0.0 \%$ \\
Fair knowledge $(60-75 \%)$ & 0 & $0.0 \%$ \\
\hline Good knowledge $(>75 \%)$ & 0 & $0-59 \%$ \\
\hline Range & \multicolumn{2}{|c|}{$13.92 \% \pm 12.33 \%$} \\
\hline Mean \pm SD & \multicolumn{2}{|c|}{17.65} \\
\hline
\end{tabular}

Table (4) shows the relationship between parasitic infections and student's profile. A significant difference was found between the infected and non-infected students in relation to birth order $(p=0.036)$.

Table (4): Relationship between parasitic infections and students' profile.

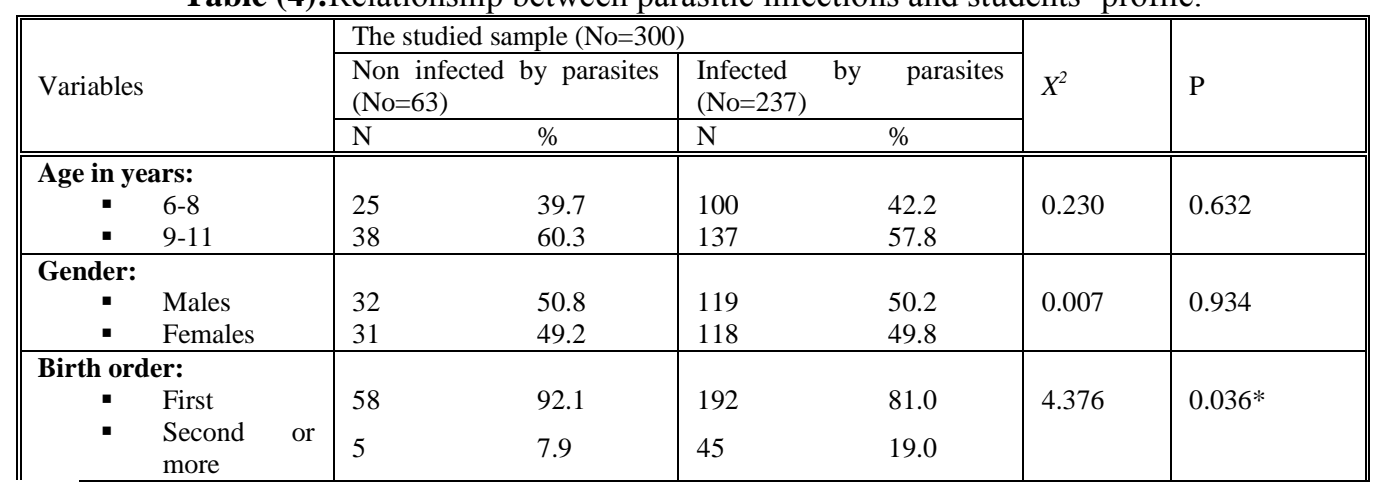

*Significant

Table (5) showed therelationship of studied students to parasitic infection and their personal hygiene measures. The table illustrated that, nearly the percentage of non-infected students with parasites who adhere to most of all elements of personal hygiene measures were more than of infected students with no statistical significant difference between infected and non-infected students regarding all elements of personal hygiene measures $(\mathrm{p}<0.05)$.

Table (5):Relationship of studied students to parasitic infection and their personal hygiene measures.

\begin{tabular}{|c|c|c|c|c|c|c|c|}
\hline \multirow[t]{2}{*}{ Variables } & \multicolumn{2}{|c|}{$\begin{array}{l}\text { Non infected by } \\
\text { parasites }(n=63)\end{array}$} & \multicolumn{2}{|c|}{$\begin{array}{c}\text { Infected by parasites } \\
(\mathrm{n}=237)\end{array}$} & \multicolumn{2}{|c|}{$\begin{array}{c}\text { Total } \\
(\mathrm{n}=300)\end{array}$} & \multirow[t]{2}{*}{$\mathrm{p}$} \\
\hline & $\mathrm{N}$ & $\%$ & $\mathrm{~N}$ & $\%$ & $\mathrm{~N}$ & $\%$ & \\
\hline $\begin{array}{c}\text { Bathing in winter per week } \\
\text { - Once / week } \\
\text { - } \quad \text { Twice /week } \\
\text { - } \quad \text { Three or more / week }\end{array}$ & $\begin{array}{l}17 \\
22 \\
24\end{array}$ & $\begin{array}{l}27.0 \\
34.9 \\
38.1 \\
\end{array}$ & $\begin{array}{l}81 \\
88 \\
68 \\
\end{array}$ & $\begin{array}{l}34.1 \\
37.1 \\
28.7\end{array}$ & $\begin{array}{l}98 \\
110 \\
92 \\
\end{array}$ & $\begin{array}{l}32.7 \\
36.7 \\
30.6 \\
\end{array}$ & 0.517 \\
\hline $\begin{array}{c}\text { bathing in summer per week: } \\
\text { - } \quad \text { Daily } \\
\text { - } \quad \text { Once /week } \\
\text { - } \quad \text { Twice /week } \\
\text { - Three or more / week }\end{array}$ & $\begin{array}{l}22 \\
0 \\
3 \\
38\end{array}$ & $\begin{array}{l}34.9 \\
0.0 \\
4.8 \\
60.3\end{array}$ & $\begin{array}{l}78 \\
2 \\
15 \\
142\end{array}$ & $\begin{array}{l}32.9 \\
0.8 \\
6.3 \\
59.9\end{array}$ & $\begin{array}{l}100 \\
2 \\
18 \\
180\end{array}$ & $\begin{array}{l}33.3 \\
0.7 \\
6.0 \\
60\end{array}$ & 0.976 \\
\hline $\begin{array}{cc}\text { Share underwear clothes } \\
\text { - } \quad \text { Yes } \\
\text { - } \quad \mathrm{NO} \\
\end{array}$ & $\begin{array}{l}12 \\
51 \\
\end{array}$ & $\begin{array}{l}19.0 \\
81 \\
\end{array}$ & $\begin{array}{l}43 \\
194 \\
\end{array}$ & $\begin{array}{l}18.1 \\
81.9 \\
\end{array}$ & $\begin{array}{l}55 \\
245 \\
\end{array}$ & $\begin{array}{l}18.3 \\
81.7 \\
\end{array}$ & 0.856 \\
\hline $\begin{aligned} & \text { Hand washing before eating: } \\
& \text { - } \text { None } \\
& \text {. } \text { With water only } \\
& \text {. } \text { With soap and water }\end{aligned}$ & $\begin{array}{l}2 \\
6 \\
55\end{array}$ & $\begin{array}{l}3.2 \\
9.5 \\
87.3\end{array}$ & $\begin{array}{l}8 \\
23 \\
206\end{array}$ & $\begin{array}{l}3.4 \\
9.7 \\
86.9 \\
\end{array}$ & $\begin{array}{l}10 \\
29 \\
261 \\
\end{array}$ & $\begin{array}{l}3.3 \\
9.7 \\
87.0\end{array}$ & 1.000 \\
\hline $\begin{array}{l}\text { Hand washing before eating at } \\
\text { school: } \\
\text { - } \quad \text { None } \\
\text { - With water only } \\
\text { - With soap and water }\end{array}$ & $\begin{array}{l}28 \\
25 \\
10 \\
\end{array}$ & $\begin{array}{l}44.4 \\
39.7 \\
15.9 \\
\end{array}$ & $\begin{array}{l}104 \\
90 \\
43 \\
\end{array}$ & $\begin{array}{l}43.9 \\
38.0 \\
18.1 \\
\end{array}$ & $\begin{array}{l}132 \\
115 \\
53 \\
\end{array}$ & $\begin{array}{l}44.0 \\
38.3 \\
17.7 \\
\end{array}$ & 0.907 \\
\hline $\begin{array}{c}\text { Hand washing after toilets: } \\
\text { - } \quad \text { None } \\
\text { - } \quad \text { With water only } \\
\text { With soap and water }\end{array}$ & $\begin{array}{l}4 \\
4 \\
55\end{array}$ & $\begin{array}{l}6.3 \\
6.3 \\
87.3 \\
\end{array}$ & $\begin{array}{l}6 \\
32 \\
199 \\
\end{array}$ & $\begin{array}{l}2.5 \\
13.5 \\
84.0 \\
\end{array}$ & $\begin{array}{l}10 \\
36 \\
254 \\
\end{array}$ & $\begin{array}{l}3.3 \\
12.0 \\
84.7 \\
\end{array}$ & 0.093 \\
\hline
\end{tabular}


Prevalence of parasitic Infections and its Effect on the Health Status of Primary School Children.

*Significant

Figure (3) showed the relationship between parasitic infections and degree of anemia as measured by hemoglobin level. The figure illustrated that, about three quarter of infected students by parasites $(75.5 \%)$ had moderate anemia compared to less than one quarter $(23.8 \%)$ of non-infected students. On the other hand, $(17.5 \%$, and $8.9 \%$ ) of non-infected and infected students by parasites respectively had no anemia. Furthermore, slightly more than half of non-infected students (58.7\%) had mild anemia compared to (15.7\%) of infected students. There was a statistical difference between the two groups of students in relation to their hemoglobin levels $\left(X^{2}=61.549, \mathrm{p}=0.001\right)$.

Figure (3): Relationship between parasitic infections and degree of anemia as measured by hemoglobin level.

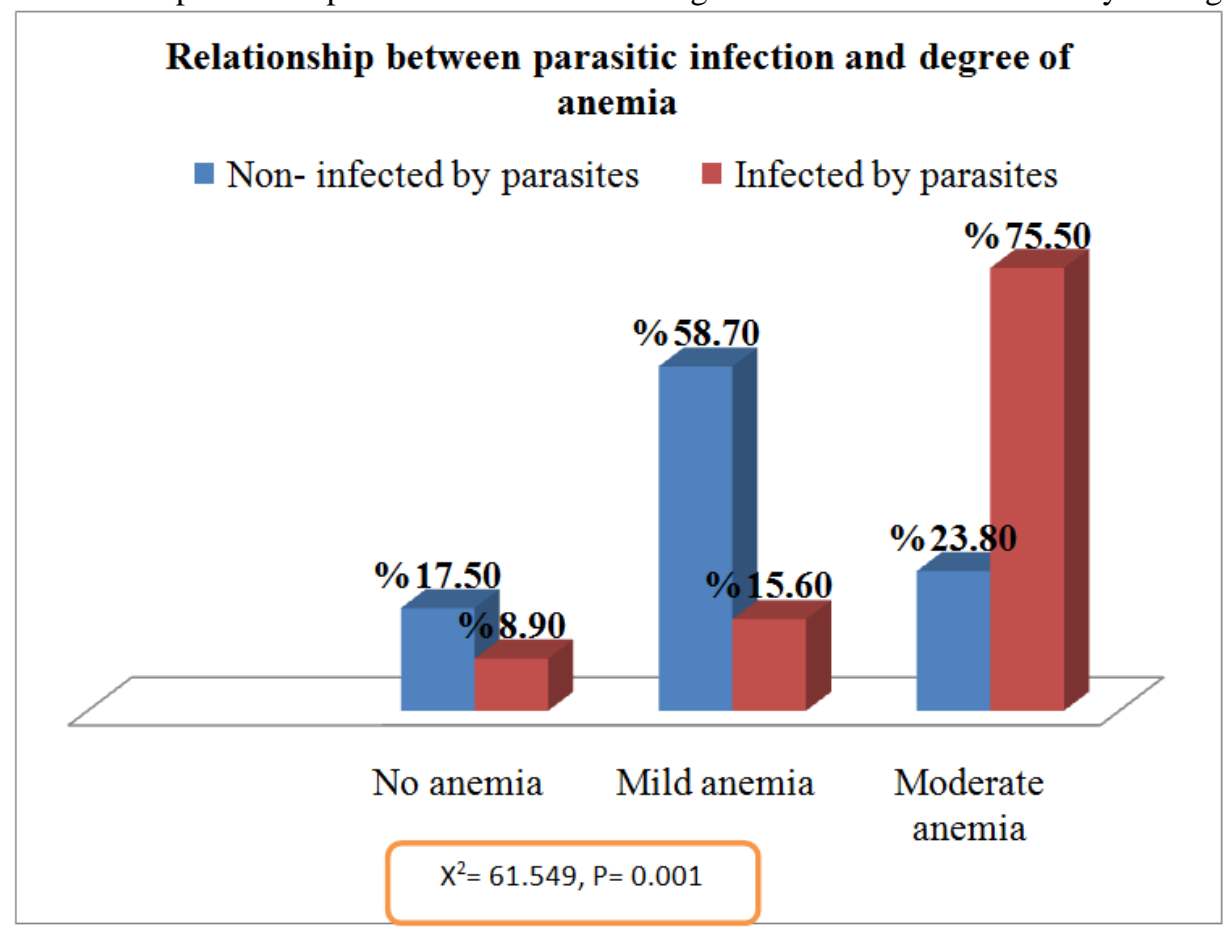

Table (6) illustrated the relationship between studied students' parasitic infection and their body mass index (BMI). The table illustrated that, about three quarter $(76.2 \%, 75.0 \%$ and $78.3 \%)$ of the three groups (noninfected students, studentsinfected by one parasite and those infected by two parasites) respectively, were at normal weight compared to $(4.8 \%, 8.3 \%$ and $5.3 \%$ ) of the three groups (non-infected students, studentsinfected by one parasite and those infected by two parasites) respectively, were below normal weight with no significant difference between three groups $(\mathrm{p}=0.947)$.

Table (6): Relationship between studied students' parasitic infections and their body mass index (BMI).

\begin{tabular}{||l|cc|cc|cc||}
\hline \multirow{2}{*}{ Body mass index (BMI) } & \multicolumn{2}{|c|}{$\begin{array}{c}\text { Non infected by } \\
\text { parasites (63) }\end{array}$} & \multicolumn{2}{|c|}{$\begin{array}{c}\text { Infected by one Parasite } \\
(168)\end{array}$} & \multicolumn{2}{c|}{$\begin{array}{c}\text { Infected by Two } \\
\text { parasites (69) }\end{array}$} \\
\cline { 2 - 7 } & $\mathrm{N}$ & $\%$ & $\mathrm{~N}$ & $\%$ & $\mathrm{~N}$ & $\%$ \\
\hline - Below normal & 3 & 4.8 & 14 & 8.3 & 4 & 5.8 \\
Normal & 48 & 76.2 & 126 & 75.0 & 54 & 78.3 \\
Overweight & 7 & 11.1 & 19 & 11.3 & 8 & 11.6 \\
Obese & 5 & 7.9 & 9 & 5.4 & 3 & 4.3 \\
\hline
\end{tabular}

Table (7) showed the distribution of studied students in relation to parasitic infection and physical manifestations of malnutrition. It was observed that the percentage of non-infected students (84.1\%) who had no hair manifestation was greater than that of students infected with one and two parasite $(73.2 \%$ and $65.2 \%)$ respectively. On the other hand,the percentage ofstudents infected with one or two parasites $(6.0 \%, 14.4 \%)$ respectively who had brittle hair as a sign of malnutrition was greater than that of non- infected students $(3.2 \%)$ with significant difference between 3 groups $(\mathrm{p}=0.047$ and $\mathrm{p}=0.026)$ respectively.

Concerning face manifestation, it was observed that the percentage of non-infected students $(31.7 \%)$ who had no face manifestation was greater than that of students infected with one and two parasite $(9.5 \%$ and $0.0 \%)$. On the other hand, the percentage of students infected with one or two parasites (78.0\% and $92.8 \%)$ who 
had pale face as a sign of malnutrition was greater than that of non- infected students $(63.5 \%)$ with no significant difference between 3 groups ( $\mathrm{p}<0.05)$.

Table (7): Distribution of studied students in relation to parasitic infection and physical manifestations of malnutrition

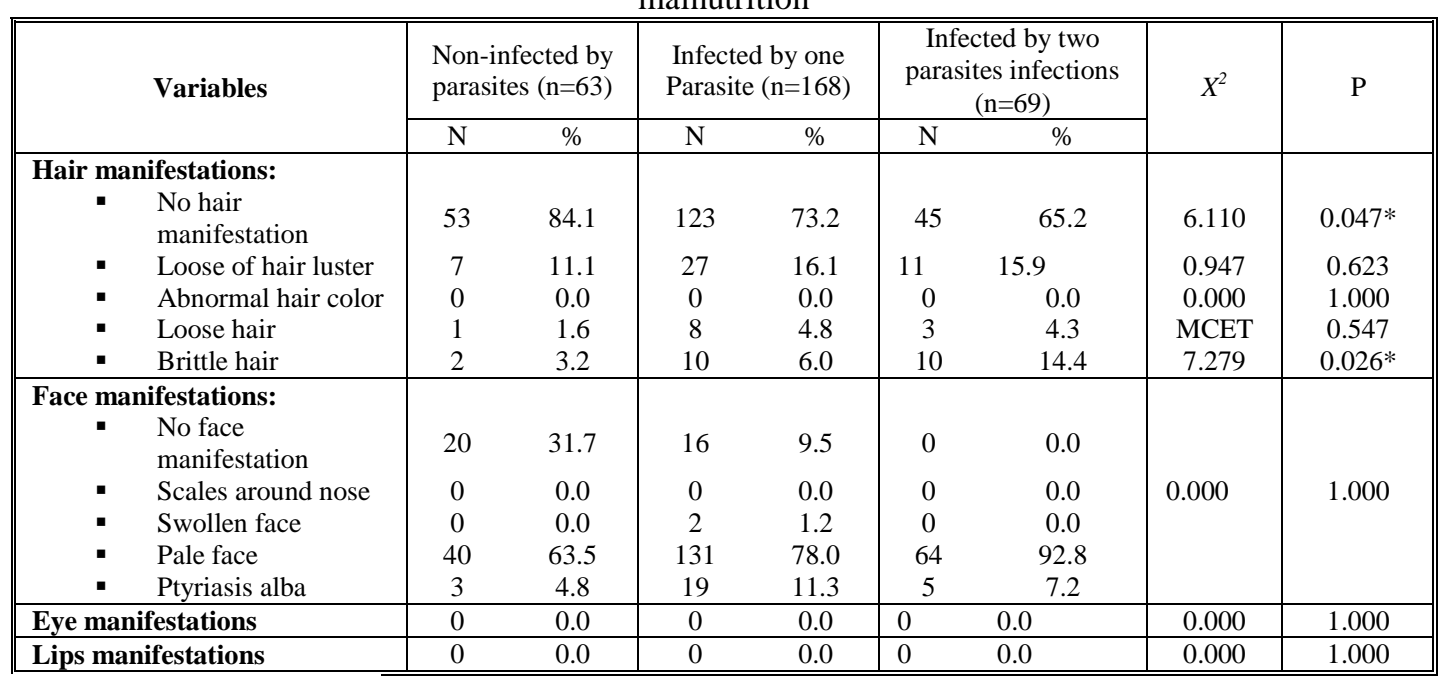

MCET $=$ Monte Carlo exact test

*Significant

Table (8) showed the distribution of studied students according to their total Mini Nutritional Assessment Scale (MNAS) score. The table illustrated that more than half $(60.3 \%)$ of non-infected students by parasites were mal nourished ( $<3$ points) compared to $(66.7 \%, 62.3 \%)$ of students infected by one parasite and those infected by two parasites respectively. The table also showed that about one third (36.5\%) of non-infected students were at risk of mal nutrition (3-4 points) compared to $(31.5 \%, 37.7 \%)$ of students infected by one parasite and those infected by two parasites respectively and only $(3.2 \%, 1.8 \%)$ of non-infected students and students infected by one parasite respectively were at normal nutritional status (4.5- 6 points) with no significant difference between 3 groups $(\mathrm{p}=0.580)$.

Table (8): Distribution of studied students according to their total MNAS score.

\begin{tabular}{||l|l|l|l|l|l|l||}
\hline \hline \multirow{2}{*}{ Total MNAS score } & \multicolumn{2}{l|}{$\begin{array}{l}\text { Non- infected by } \\
\text { parasites (n=63) }\end{array}$} & \multicolumn{2}{l|}{$\begin{array}{l}\text { Infected by one } \\
\text { parasite }(\mathrm{n}=168)\end{array}$} & \multicolumn{2}{l|}{$\begin{array}{l}\text { Infected by two parasites } \\
(\mathrm{n}=69)\end{array}$} \\
\cline { 2 - 8 } & $\mathrm{n}$ & $\%$ & $\mathrm{~N}$ & $\%$ & $\mathrm{n}$ & $\%$ \\
\hline \hline$-\begin{array}{l}\text { Mal nourished (<3 points) } \\
\begin{array}{l}\text { At risk of mal nutrition (3-4 } \\
\text { points) }\end{array}\end{array}$ & 38 & 60.3 & 112 & 66.7 & 43 & 62.3 \\
$\begin{array}{l}\text { Normal nutritional status } \\
\text { (4.5-6 points) }\end{array}$ & 23 & 36.5 & 53 & 31.5 & 26 & 37.7 \\
\hline
\end{tabular}

$\mathrm{P}=0.580$ (Not Significant)

\section{Discussion}

Intestinal parasites are among the most common infections of school age children, particularly in developing countries. The high frequency of intestinal parasites in a population of a region indicates low socioeconomic development or conditions, poor medical care, occupational exposure and low standard of hygiene ${ }^{(31)}$. Therefore, the aim of this study was to assess the prevalence of helminthic infection and its effect on the health status of primary school children. The present study showed that there was higher prevalence of parasitic infection among the studied school children in which, more than three quarter of the studied school children (79\%) was infected by intestinal parasite (figure 1), and all of the studied school children had poor knowledge about intestinal parasitic infection (table 3). Finally, as a bad impact of intestinal parasitic infection, about three quarter $(75.5 \%)$ of the infected students had moderate anemia(figure 3 ). The present study showed that, the studied students' age ranged from 6-11years with a mean of $8.82 \pm 1.77$ years and nearly males and females were equal numbers (table 1). However, Tetteh $\mathbf{( 2 0 1 2}^{(32)}$, who found that about $(48.42 \%)$ of the studied students were males and about $(51.58 \%)$ of them were females with the ages from 5-12 years. Also, another study done by Haftu et al., (2014) ${ }^{(33)}$, revealed that $(48.8 \%)$ of the studied children were males and $(51.2 \%)$ were females with a mean 10.72(+2.55) years. this difference in age may be due to change of age at starting of elementary education in different countries. Regarding history of parasitic infections, the present study revealed that less than two thirds of the studied students had previous personal history of parasitic infection (table 2). This may be due to school children immune systems are not fully developed and their playing and hygiene practices put them 
at frequent risk of infection than other age groups. However, Bauomy et al., (2010) ${ }^{(34)}$, reported that, about one half of studied students had previous history of parasitic infection.

As regard to the prevalence of parasitic infections among the studied school children, the present study showed that more than three quarter of the studied school children were infected by intestinal parasites (figure1). The high prevalence of parasitic infection in the present study was related to poor rural environmental sanitation and poor personal hygiene. This result was similar to the study of Uga et al., (2005) ${ }^{(35)}$, who reported that, the prevalence of parasitic infection among school children in a sub urban area of Hanoi, Vietnam was about three quarter $(76 \%)$ of school children positive for at least one type of parasites. Also this study is in agreement with Ullah et al., (2014) ${ }^{(36)}$, who reported that the percentage of parasitic infection among school children was (73.87\%). Another study conducted by Ashok et al., (2013) ${ }^{(37)}$, showed high prevalence of parasitic infection 63.9\%. However, our result was higher than several studies done in Egypt which include a study done in Damietta Governorate by Mohammad et al., (2012) ${ }^{(38)}$, a study done in Al-Azhar and Assiut university hospitals by Bauomy et al., (2010) ${ }^{(34)}$ and a study done in Tanta, Gharbia Governorate by Ahmed (2013) ${ }^{(39)}$, which they reported that about one third and about one quarter $(30.7 \%, 38.5 \%$ and $22.43 \%)$ of school pupils respectively had intestinal parasitic infections.

The most common intestinal parasites among the studied students were entemebahistolytica followed by oxyuris, ascaris, giardia lamblia and hymenlopis nana (figure 2). This could be due to poor environmental sanitation and poor personal hygiene which associated with Entamoebahistolytica, oxyuris and ascaris [as only small percentage of the studied students $(17.7 \%)$ washed their hands with soap and water before eating at schools (table 5)]. Or it may be due to poor water sanitation which commonly associated with giardia lamblia. This is in accordance with Hussein $(2011)^{(40)}$, who reported that the most common intestinal parasite was entemebahistolytica followed by giardia lamblia, oxyuris and ascaris. Also, the study done by Mwenji $(2010)^{(41)}$, showed that the highest number of infections was caused by Entamoebahistolytica. As reported by El-Masry et al., (2007) $)^{(42)}$, the most common intestinal parasite was entemebahistolytica followed by oxyuris, giardia lamblia, hymenlopis nana and Ascarislumbricoides.

On the other hand, This result is in contrast with Hamed et al., (2013) ${ }^{(43)}$, who reported that the most common intestinal parasites among the study participants in Sohag Governorate, Egypt, were oxyuris followed by amoebiasis, giardiasis, and H. nana. Also, this result is in contrast with Jimenez et al., (2013) ${ }^{(44)}$, who reported that, the most common intestinal parasite among the study participants wasascarislumbricoides. In addition, Masoumehet al., (2012) ${ }^{(45)}$, reported that, the most common intestinal parasites among the studied school children were giardia intestinals and hymelonlepis nana. The differences in findings among the studies regarding the most commonly prevalent parasites can be explained by variations in the main primary cause of infection among different countries.

As regard knowledge of the studied students about parasitic infection, all studied students had poor knowledge (table 3). This result could be due to lack of education of the students' parents as less than half of them were illiterate or read and writeand this lead to lack of knowledge and awareness about parasitic infection among parents and their children. The present result is in accordance with Zakai (2007) ${ }^{(46)}$, who reported that about two thirds of the studied subject had a below average degree of awareness about parasites and parasitic diseases.Nutrition has become very important in both preventive and curative health care ${ }^{47)}$. Concerning the distribution of studied students according to their total Mini Nutritional Assessment Scale (MNAS) score, about two thirds $(66.7 \%, 62.3 \%)$ of students infected by one parasite and those infected by two parasites were mal nourished respectively(table 8). This result may be attributed to lack of awareness of student's parents about essential elements of good nutrition This result is in agreement with Sultanah et al., (2015) ${ }^{(48)}$. But Reji et al., $(2011)^{(49)}$, reported that less than one quarter of the studied school children were malnourished.

As regard the relationship between studied students' parasitic infection and their body mass index (BMI), the present study revealed that about three quarter of the non-infected students, students infected by one parasite and those infected by two parasites were at normal weight compared to few of the three groupswere below normal weightwith no significant difference between them $(\mathrm{p}=0.947)$ (table 6). This may be attributed to that parasitic infection was recent and their bad impact didn't develop on infected students. This is in the line with Oluboyo et al., (2014) ${ }^{(50)}$, who reported that the majority of the studied students were at normal weight and $(8.1 \%)$ of the children were found to be underweight with no significant changes were observed in the BMI of children who had parasitic infections in relation to children free of such infections $(\mathrm{P}>0.05)$. Also, a study conducted by Mobarak et al., (2011) ${ }^{(51)}$, revealed that, about more than half of the studied children were at normal weight and about one third of the studied children were underweight.

Regarding the relationship between parasitic infections and student's profile, the present study revealed that there was no statistical significant difference between both groups of students (non-infected and infected students by parasites) regarding their age $(\mathrm{p}=0.632)$, and gender $(\mathrm{p}=0.934)$ (table 5). This indicated that the age and gender may not play the primary role in parasitic infection depending up on the region and other environmental or behavioral factors. This is in agreement withGelaw et al., (2013) ${ }^{(52)}$ andKhadka et al., (2013) 
${ }^{(53)}$. However our result is in contrast with Messaad et al., $(2014){ }^{(54)}$ who found that there was a statistical significant difference between the prevalence of intestinal parasiticinfections among children and their age and sex.

Regarding the relationship between studied students with parasitic infection and their personal hygiene measures, the present study revealed that there was no statistical significant difference between infected and non-infected students regarding hand washing after toilets (table 5). This is in the line withSaka et al., (2014) ${ }^{(55)}$, andHaftu et al., (2014) ${ }^{(33)}$. On the other hand Al-Mohammed et al., (2010) ${ }^{(56)}$, and Sah et al., (2013) ${ }^{(57)}$ found that hand washing after defecation was significantly associated with the prevalence of intestinal parasitic infection.

The present study revealed that, about three quarter of infected students by parasites and slightly less than one quarter of non-infected students by parasites respectively, had moderate anemia and more than half of non-infected students by parasites and about (15.7\%) of infected students had mild anemia (figure 3 ). This may be attributed to poor nutritional status of school children due to lack of awareness of student's parents about essential elements of good nutrition. Moreover, it may be related to high prevalence of parasitic infection among school children (figure 1) which leads to loss of appetite as a consequences of infection and in turn deficiency in nutritional intake that predispose to anemia. This is in contrast with Munisi (2012) ${ }^{(58)}$, who found that, only (3.1\%) of school children had anemia. However, a study done by Janice et al., (2014) ${ }^{(59)}$, found that only $(18.3 \%)$ of the studied school children had anemia.

Finally, the present study revealed that about three quarter of the studied schoolchildren was infected by intestinal parasites. This is in addition to the fact that, all of the studied school children had poor knowledge about intestinal parasitic infections. This directs the light toward school nurse's role toward improving school children knowledge about intestinal parasitic infections and helping them to follow preventive measures.

\section{Conclusion}

Based on the findings of the present study, it can be concluded that, more than three quarter of the primary school children in rural were infected by intestinal parasites particularlyEntemebaHistolytica. All of the studied students had poor knowledge score about intestinal parasitic infections and about three quarter $(75.5 \%)$ of the infected students by parasites had a moderate anemia with significant association between parasitic infection and hemoglobin level.

\section{Recommendations}

1- School health nurse should develop health education programs about intestinal parasitic infections for students and for the public to improve their personal and environmental hygienic measures to keep the level of sanitation high.

2- Regular screening for parasite infestation among schoolchildren is necessary as part of the school health program.

3- Mass media programs are needed to help in disseminating information about intestinal parasitic infection to large sector of the community as it is one of the neglected tropical diseases.

\section{References}

[1] Hockenberry M and Wilson D. Wong's Essentials of Pediatric Nursing. $9^{\text {th }}$ ed. United States of America: Library of congress Cataloging in publication data Co, 2013; 458 .

[2] Hattingh S, Dreyer M and Roos S. Community Nursing. $4^{\text {th }}$ ed. Southran Africa: Southran Co, 2012; 305-308.

[3] Amein N, Bader EL-Din S, Bayomi S, Hossein Y. Knowledge and Practice of Caregivers about Intestinal Parasitic Infestations at EL- Minia City. Journal of Education and Practice, 2014; 5 (3): 105.

[4] Allender J, Rector C and Warner K. Community Health Nursing, Promoting and Protecting the Public's Health. $7^{\text {th }}$ ed. Philadelphia: Wolters Kluwer/ Lippincott Williams \& Wilkins Co, 2010; 608.

[5] Aher A and Kulkarni S. Prevalence of Intestinal Parasites in School Going Children in a Rural Community International Journal of Biomedical Research, 2011; 2(12): 605-607.

[6] Shrestha A, Narayan K and Sharma R. Prevalence of Intestinal Parasitosis among School Children in Baglung District of Western Nepal. Kathmandu university medical journal, 2012; 10(1):3-6.

[7] Tiwari B, Chaudhary R, Adhikari N, Jayaswal S, Poudel T and RijalK.Prevalence of Intestinal Parasitic Infections among School Children of Dadeldhura District, Nepal.JHAS, 2013; 3(1): 14-16.

[8] World Health Organization. Soil-transmitted helminth infections: Who report, 2014. Available at: http://www.who.int/mediacentre/factsheets/fs366/en/5

[9] Bauomy A, Hamed A, Abdelaziz N ,Abdeltawab A, Monazea E, AbdElkreem H and Mohamed S. Prevalence and Risk Factors Associated With Worm Infestation in School Aged Children in Al- Azhar and Assiut University Hospitals. AAMJ, 2010; 8 (3): 8891.

[10] Ibrahium F. Prevalence and Predisposing Factors Regarding Intestinal Parasitic Infections among Rural Primary School Pupils at Minia Governorate, Egypt. Journal of Public Health in Africa, 2011; 2(29): 123-126.

[11] Mohammad K, Mohammad A, Abu El-Nour M, Saad M, andTimash A. The Prevalence and Associated Risk Factors of IntestinalParasitic Infections among School Children Living in Rural andUrban Communities in Damietta Governorate. Academia ArenaJournal, 2012; 4(5): 92. 
[12] Ogbuagu C, Eneanya C, Chukwuma C, Ogbuagu E and Oguoma V. High Prevalence of Intestinal Parasites in a Nigerian Tertiary Health Institution. The Internet Journal of Parasitic Diseases, 2009; 4 (2):1-7.

[13] James S, Nelson K and Aswill J. Nursing Care Of Children. $4^{\text {th }}$ ed. China: Elsevier Saunders Co, 2013; 377.

[14] Ghai O, Paul V and Bagga K. Essentials Pediatrics. $7^{\text {th }}$ ed. India: Bangalore Co, 2009; 481- 485.

[15] Battle C. Essentials of Public Health Biology. London: Jones and Bartlett Co, 2009; 286-296.

[16] Nkiru A. Kamalu, Felicia E. Uwakwe and Jacinta A. Prevalence of Intestinal Parasite among High School Students in Nigeria.Academic Journal of Interdisciplinary Studies, 2013; 2(7): 11.

[17] Kenneth N. Opara, Nsima I. Udoidung, Dominic C. Opara, Okpok E. Okon, Evelyn U. Edosomwan, and Anietie J. Udoh. The impact of intestinal parasitic infections on the nutritional status of rural and urban school-aged Children in Nigeria. International Journal of MCH and AIDS, 2012; 1 (1): 74.

[18] ParulDatta. Pediatric nursing.New Delhi: Jaypee brother medical publishers Co; 2007:265-267.

[19] Wegayehu T, Tsalla T, Seifu B and Teklu T. Prevalence of Intestinal Parasitic Infections among Highland and Lowland Dwellers InGamo Area, South Ethiopia. BMC Public Health, 2013; 13(151): 1-7. Available at: http://www.biomedcentral.com/14712458/13/151 page 1

[20] Ashok R, Suguneswari G, Satish K and Kesavaram V. Prevalence of Intestinal Parasitic Infection in School Going Children in Amalapuram, Andhra Pradesh, India. Shiraz E-Med J, 2013;14(4): 1-4.

[21] Cepon-Robins T, Liebert M, Gildner T, Urlacher S, Colehour A, Snodgrass J, Madimenos F, and Sugiyama L. Soil-Transmitted Helminth Prevalence and Infection Intensity Among Geographically and Economically Distinct Shuar Communities in the Ecuadorian Amazon. Journal of Parasitology,2014; 100(5):598-607.

[22] Shah S. Pediatric Practice: Infectious Disease. London: Mc Grow- Hill Co, 2009; 701-716.

[23] Belizario V, Tuliao A, Totanes F and Asuncion C. Optimizing School-Based Intestinal Helminth Control Interventions in the Philippines. Pediatric Infectious Disease Society of the Philippines Journal, 2013; 14(1): 1-12.

[24] World Health Organization (WHO). Accelerating Work to Overcome the Global Impact of Neglected Tropical Diseases: A Roadmap for Implementation. Geneva, 2012. Available at: www.who.int/neglected_diseases/en

[25] Prabhakara G. Text Book of Community Health for Nurses. $2^{\text {nd }}$ ed. New Delhi :Peepee Co, 2009; 366 -382.

[26] Ghai O, Paul V and Bagga K. Essentials Pediatrics. $7^{\text {th }}$ ed. India: Bangalore Co, 2009; 481- 485.

[27] The West African Center for International Parasite Control, Noguchi Memorial Institute for Medical research and Japan International Cooperation Agency. Project document report. 2004; 13-14. Available at: www.noguchimedres.org/wacipac/pdf/Project-doc

[28] Dudeek, S. G. Nutrition Essentials for Nursing Practice. $4^{\text {th }}$ ed. Batlimore. Lippincott. 2001; pp516.

[29] WHO. Indicators and Strategies for Iron Deficiency Anemia Programs. Report of WHO/UNICIEF/UNU Consultation, World Health Organization, 1994.

[30] Nestle Nutrition Institute. Mini Nutritional Assessment (MNA). 1994. revised 2009 available at: www.mna-elderly.com

[31] Zaglool D, Khodari Y, Gazzaz Z, Dhafar K, Shaker H and Farooq M. Prevalence of Intestinal Parasites among Patients of Al-Noor Specialist Hospital, Makkah, Saudi Arabia. Oman Medical Journal, 2011; 26(3): 182-185.

[32] Tetteh P. A Comparative Study of Intestinal Parasitic Infection and Associated Risk Factors among Primary School Children in Six Neighbouring Communities in Kumasi, Ghana: Ayigya, Kentinkrono, Aboabo, Manhyia, Gyinyase and Kyirapatre. Published Master Thesis. School of medical sciences, Kwame Nkrumah University, Ghana, 2012.

[33] Haftu D, Deyessa N and Agedew E. Prevalence and Determinant Factors of Intestinal Parasites among School Children in Arba Minch town, Southern Ethiopia. American Journal of Health Research, 2014; 2(5): 247-254.

[34] Bauomy A, Hamed A, Abdelaziz N ,Abdeltawab A, Monazea E, AbdElkreem H and Mohamed S. Prevalence and Risk Factors Associated With Worm Infestation in School Aged Children in Al-Azhar and Assiut University Hospitals. AAMJ, 2010; 8 (3): 88 91.

[35] Uga S, Hoa N, Thuan L, Noda S and Fujimaki Y. Intestinal parasitic infections in schoolchildren in a suburban area of Hanoi, Vietnam. Tropical Medical Public Health Journal, 2005; 36(6): 1407-1411.

[36] Ullah W, Shah A, Jamal Q, Ullah S, Muhammad I and Ullah H. Prevalence of Intestinal Parasites among School Children in District Upper Dir, Khyber Pakhtunkhwa Pakistan. International Journal of Biosciences, 2014; 5(1): 1-8.

[37] Ashok R, Suguneswari G, Satish K and Kesavaram V. Prevalence of Intestinal Parasitic Infection in School Going Children in Amalapuram, Andhra Pradesh, India. Shiraz E Medical Journal, 2013; 14(4):1-4.

[38] Mohammad K, Mohammad A, Abu El-Nour M, Saad M, and Timash A. The Prevalence and Associated Risk Factors of Intestinal Parasitic Infections among School Children Living in Rural and Urban Communities in Damietta Governorate. Academia Arena journal, 2012; 4(5): 92

[39] Ahmed W. Intestinal Parasites among Primary School Children in Urban and Rural Tanta, Gharbia, Governorate, Egypt. The Egyptian Society of Experimental Biology Journal, 2013; 9(2): $257-262$

[40] Hussein A. Prevalence of Intestinal Parasites among School Children in Northern Districts of West Bank- Palestine. Tropical Medicine and International Health journal, 2011; 16(2): 240-244.

[41] Mwenji B. The Influence of Intestinal Parasites on Academic Performance among Primary School Children in Nairobi Province, Kenya. Published Master Thesis. School of Health Sciences, Kenyatta University, Kenya, 2010.

[42] El-Masry H, Ahmed Y, Hassan A, Zaky S, Abd-Allah E, El-Moselhy E, Baraka Y and Abdel-Rahem M. Prevalence, Risk Factors and Impacts of Schistosomal and Intestinal Parasitic Infections among Rural School Children in Sohag Governorate. The Egyptian Journal of Hospital Medicine, 2010; 29: 616- 630.

[43] Hamed A, Yousef F, Omran E and Moustafa A. Common Parasitic Infestation among Rural Population in Sohag Governorate, Egypt. Journal of American Science, 2013; 9(4): 596-601.

[44] Jimenez J, Sanchez M, Martinez L, Guzman M, Cazares L, Esquinca A, Fuentes S and Vidal J. Malnutrition and the Presence of Intestinal Parasites in Children from the Poorest Municipalities of Mexico. J Infect DevCtries, 2013; 7(10):741-747.

[45] Masoumch R, Farideh T, Mitra S and Heshmatollah T. Intestinal Parasitic Infection among School Children in Golestan Province, Iran. Pakistan journal of biological science, 2012; 15(23): 1119-1125.

[46] Zakai H. Level of Awareness about Parasitic Diseases among Students, Jeddah, Saudi Arabia. JKAU, 2007; 14(2): 37-47.

[47] Mekonnen H, TadesseTand Kisi T. Malnutrition and its Correlates among Rural Primary School Children of Fogera District, Northwest Ethiopia. J Nutritional Disorders Therapy, 2013; 1-7.

[48] Sultana S, Akther N, Chowdhury S, Sarwar K, Begum M, Lata N, Sabnom R and Begum N. Intestinal Parasitic Infestation and Hygiene Practices among the Street Children. European academic research J, 2015; 2(11): 14277- 14291.

[49] Reji P, Belay G, Erko B, Legesse M and Belay M. Intestinal Parasitic Infections and Malnutrition amongst First-Cycle Primary Schoolchildren in Adama, Ethiopia. Afr J Prm Health Care Fam Med, 2011; 3(1): 1-5. 
[50] Oluboyo B, Enweani I, Ekejindu I and Oluboyo A. Prevalence of Some Intestinal Parasitic Infections in Relation to Body Mass Index of Children Resident in Orphanages in AnambraState,Nigeria. European Scientific Journal, 2014; 10(36): 221 -222

[51] Mobarak A, Mohamed N and Abd El-Kariem H. Effect of Health Education Program for Mothers of Children with EnterobiusVermicularis at Assiut University Children Hospital. AAMJ, 2011; 9(1): 277-306.

[52] Gelaw A, Anagaw B, Nigussie B, Silesh B, Yirga A, Alem M, Endris M and Gelaw B. Prevalence of intestinal parasitic infections and risk factors among schoolchildren at the University of Gondar Community School, Northwest Ethiopia: a cross-sectional study. Bio Medical Center Public Health Journal, 2013; 13 (304): 2-7.

[53] Khadka K, Kaphle H, Gurung K, Shah Y and Sigdel M. Study of Intestinal Parasitosis among School Going Children in Pokhara, Nepal. JHAS, 2013; 3(1): 47-50.

[54] Messaad S, Laboudi M, Moumni M, Sarhane B, Belghyti D and El Kharrim K. Children Intestinal Parasites Related to SocioEconomic Factors in Salé Hospital, Morocco. International Journal of Innovation and Applied Studies, 2014; 8(2): 833-840.

[55] Saka M, Aremu A and Saka A. Soil-Transmitted Helminthiasis: Prevalence Rate and Risk Factors among Schoolchildren in Ilorin, Nigeria. Journal of Applied Sciences in Environmental Sanitation, 2014; 9 (2): 139-145.

[56] Al-Mohammed H, Amin T, Aboulmagd E, Hablus H and Zaza B. Prevalence of Intestinal Parasitic Infections and Its Relationship With Socio-Demographics and Hygienic Habits among Male Primary School children in Al-Ahsa, Saudi Arabia. Asian Pacific Journal of Tropical Medicine, 2010; 3 (11): 906-912.

[57] Sah R, Bhattarai S, Yadav S, Baral R, Jha N and Pokharel P. A study Of Prevalence of Intestinal Parasites and Associated Risk Factors among the School Children of Itahari, Eastern Region Of Nepal. Tropical Parasitology Journal, 2013; 3(2): 140-143.

[58] Munisi D. Soil-Transmitted Helminthes Infections, Malnutrition and Anaemia among Primary School Children in Same District. Published Master Thesis of Sciences. Health and Allied Sciences School, Muhimbili University, Tanzania, 2012.

[59] Janice V, Belizario V, and Claveria F. Determination of Soil-Transmitted Helminth Infection and Its Association with Hemoglobin Levels among Aeta Schoolchildren of Katutubo Village in Planas, Porac, Pampanga. Philippine Science Letters J, 2014; 7(1): 7379.

NahedKaram Mahmoud El-sehry. "Prevalence of parasitic Infections and its Effect on the Health Status of Primary School Children." IOSR Journal of Nursing and Health Science (IOSR-JNHS) 6.4 (2017): 41-52. 